\title{
A Study on the Effect of Workplace Friendship Level on Consultant's Customer Orientation
}

\section{- Focusing on the Mediating Effect of Job Commitment}

\author{
Mi-Sun Eom ${ }^{1} \&$ Yen-Yoo You ${ }^{1}$ \\ ${ }^{1}$ Dept. of Smart Convergence Consulting, Hansung University, Seoul, South Korea \\ Correspondence: Mi-Sun Eom, Dept. of Smart Convergence Consulting, Hansung University, Seoul, South Korea. \\ Tel: 82-10-2531-1424. E-mail: showsuny@daum.net
}

Received: April 9, 2020

Accepted: May 9, 2020

Online Published: May 23, 2020

doi:10.5430/rwe.v11n2p136

URL: https://doi.org/10.5430/rwe.v11n2p136

\begin{abstract}
Background/Objectives: The purpose of this study was to examine the effect of the relationship between human resources and members on the consultant's customer service orientation as a way to secure a competitive advantage in order to continuously grow and develop a consulting firm.

Methods/Statistical analysis: This study surveyed the consultants of consulting firms. The total number of samples used in the study was 180 . The survey items consisted of 33 questions and the Likert 5-point scale was used for the measurement. As an empirical analysis, SPSS 22.0 was used for frequency analysis, exploratory factor analysis, reliability analysis, correlation analysis, regression analysis, and mediation effect analysis.

Findings: According to the results of this study, the results were summarized as follows. First, Supervisor's friendship will affect the consultant's Job commitment. Second. Co-worker's friendship will affect the consultant's Job commitment. Third, Subordinate's friendship will affect the consultant's Job commitment. Fourth Supervisor's friendship will affect the consultant's customer orientation. Fifth, Co-worker's friendship will affect the consultant's customer orientation. Sixth, Subordinate's friendship will affect the consultant's customer orientation. In addition, there is no direct influence on customer orientation in the mediation of job commitment between friendship with supervisors, friends with co-workers, friends with subordinates, and consultants' customer orientation. Job involvement between friends, friends with subordinates, and consultants' customer orientation has been found to play a full mediating role as an indirect effect.

Improvements/Applications: As a means of securing sustainable competitiveness, the relationship between the level of friendship in the workplace and the customer orientation of consultants was identified. Therefore, by measuring the level of friendships for the bosses, colleagues, and subordinates in various ways, the group that had the most positive influence was identified, and the opportunity to make practical contributions was prepared. However, in the future, it is required to consider the contract type of the members of the organization, the project status of each team, and the compensation system as a control variable.
\end{abstract}

Keywords: workplace friendship, consulting industry, management consultanting, job commitment, customer orientation

\section{Introduction}

The ability to achieve and maintain an organization's competitive advantage in a rapidly changing business environment and competitive structure depends on the constructive relationships between its own human resources, its members, and its members (Lee, 2000). In particular, the consulting industry is a knowledge service industry based on knowledge services and human services. However, even if a good consulting process is provided, the value of consulting will fall if the level of human services is low. Therefore, it is necessary to focus on the constructive relationships with the members of the organization in order to provide continuous growth of consulting firms and services and value of competitive advantage. The purpose of this study is to focus on human services as a way to secure sustainable growth and competitive advantage of consulting firms. We will analyze this. 


\section{Materials and Methods}

\subsection{Characteristics of the Consulting Industry}

The consulting industry stated that the uncertainty and the importance of choices that customers face in choosing a consulting firm are very high. Objective quality measurement of intangible services, consulting, is difficult to make and quality problems due to the wrong choice of consulting firms can turn into big risks for the company. In this context, informal social ties, trust, reputation and word of mouth can play a significant role in the selection of a consulting firm. Thus, the growth competitiveness of a consulting firm and its market success depend not only on the long-term relationship with the customer, but also on the ability to build a reliable network. As a result, the quality of network relations with customer decision makers is an important competitive advantage for consulting firms (Chung, 2014).

\subsection{Concept of Friendship}

The relationships among the members of the organization, namely, friendships within the organization, are true friends who truly support each other's success and contribute to the development of the organization as well as individual happiness. For the development of the organization, it is necessary to solidify a constructive relationship, or friendship, based on trust and devotion affection between colleagues and supervisors (Kang and Kim, 2008). Friendship can be defined here as a non-exclusive complementary relationship that shares interests and values on the basis of trust and devotion affection with colleagues working together in the workplace (Kang and Kim, 2008). Despite the importance of interpersonal relations in the workplace in the core job model, insisting that there is a lack of research on the mention or impact of them, friendships in the workplace are key characteristics in the workplace, He also argued that it has a great influence on attitudes (Riordan and Griffeth, 1995).

\subsection{Job Commitment}

Job involvement is viewed as a concept that has three aspects: strong, trusting, attachment to the organization's goals and values, a commitment to be willing to make considerable efforts for the organization, and a strong desire to remain a member of the loyalty organization (Deshpande et al., 1993), It is said that the individual internalizes the organization's goals and actively intervenes in the organization to achieve the goals of the organization and to continuously meet the needs of the individual (Kim, 2007).

\subsection{Customer Orientation}

Prior studies related to customer orientation are related to the above mentioned previous studies on customer orientation. The relationship with directivity has been identified (Hoffman and Ingram, 1991). Customer orientation is defined as a collection of beliefs that prioritize customer interest without excluding all stakeholders to develop a long-term profitable company (Deshpande et al., 1993). For the customer, the employee is recognized as a company, so one of the means to improve customer satisfaction is to improve the customer orientation of the employee. Internal marketing, which emphasizes employee job satisfaction, is emphasized in the case of companies where human factors are particularly important, such as service firms (Crosby et al., 1990). Customer orientation is said to fully understand the company's target audience in order to continuously create superior value for the customer. In other words, it means to conduct corporate activities from the customer's point of view. The marketing activity of the company must be recognized from the customer's point of view and move toward improving the profit of the customer (Levitt, 1980). The focus is on the study of customer-oriented effects of customer contact salespersons to the extent that customer needs are satisfied in the interaction between employees and customers. As a result, customer orientation of employees with customers has a positive effect on organizational effectiveness such as customer satisfaction, commitment and trust (Saxe and Weitz, 1982).

\subsection{Research Model and Hypothesis}

\subsubsection{Research Model}

The purpose of this study is to focus on human services as a way of securing sustainable growth and competitive advantage of consulting firms (Mowday et al., 1979). The relationship between the members and members of the consulting firm, namely, friendship with supervisors, friendship with co-worker, and subordinate The purpose of this study was to examine whether the level of friendship has a significant influence on the consultant's job commitment, and to empirically analyze the mediating effect of job commitment on the customer orientation of consultants who provide customer-oriented services. The research model is shown in [Figure 1]. 


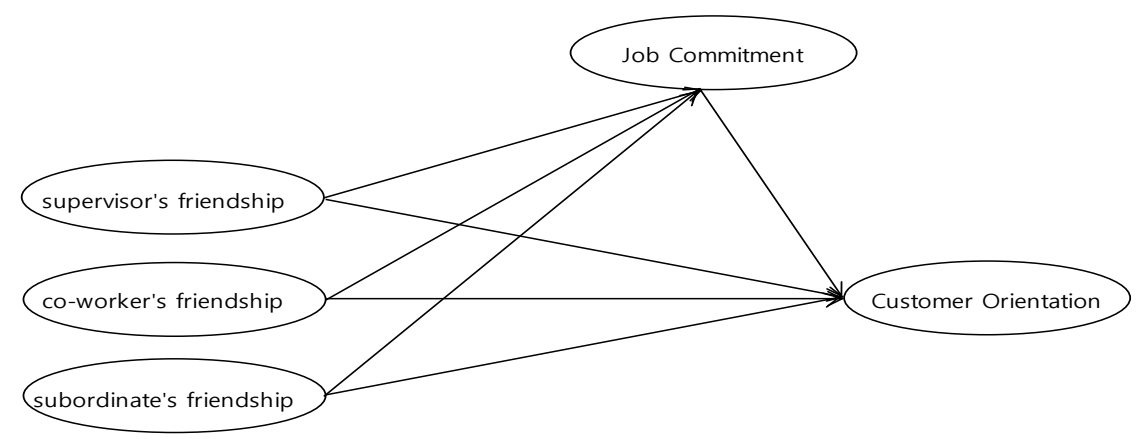

Figure 1. Research model

\subsubsection{Research Hypothesis}

Based on the prior studies, the study theory was set as follows.

H1. Supervisor's friendship will affect the consultant's Job commitment.

H2. Co-worker's friendship will affect the consultant's Job commitment.

H3. Subordinate's friendship will affect the consultant's Job commitment.

H4. Supervisor's friendship will affect the consultant's customer orientation.

H5. Co-worker's friendship will affect the consultant's customer orientation.

H6. Subordinate's friendship will affect the consultant's customer orientation.

H7. Job commitment will play a role in mediating the relationship between the supervisor's friendship with the consultant and the customer orientation.

H8. Job commitment will play a role in mediating the relationship between the Co-worker's friendship with the consultant and the customer orientation.

H9 Job commitment will play a role in mediating the relationship between the Subordinate's friendship with the consultant and the customer orientation.

\subsubsection{Operational Definition of Variables}

The operational definitions of each variable are summarized in [Table 1].

Table 1. Operational definition of variables

\begin{tabular}{|c|c|c|}
\hline variable & Operational definition & related research \\
\hline Workplace Friendship & $\begin{array}{l}\text { Non-exclusive complementary relationships that share } \\
\text { interests and values on the basis of trust, commitment and } \\
\text { affection with colleagues who work together at work }\end{array}$ & (Kang and Kim, 2008) \\
\hline Job commitment & $\begin{array}{l}\text { A concept that has three aspects: strong, trusting, attachment } \\
\text { to the organization's goals and values, a commitment to be } \\
\text { willing to make substantial efforts for the organization, and a } \\
\text { strong desire to remain a member of the loyalty organization. }\end{array}$ & (Deshpande et al., 1993) \\
\hline Customer Orientation & $\begin{array}{l}\text { A collection of beliefs that prioritize customer interest without } \\
\text { excluding all stakeholders to develop a customer-oriented } \\
\text { company that is profitable in the long term. }\end{array}$ & (Saxe and Weitz, 1982) \\
\hline
\end{tabular}




\section{Results and Discussion}

\subsection{Demographic Characteristics Analysis}

The number of samples used in this study was 180 consultants of consulting firms, and frequency analysis was conducted to investigate general characteristics. The analysis results are shown in [Table 2].

Table 2. Demographic characteristics analysis

\begin{tabular}{|c|c|c|c|c|c|}
\hline & division & frequency & $\begin{array}{l}\text { Per } \\
\text { cent }\end{array}$ & $\begin{array}{c}\text { Effective } \\
\text { percent }\end{array}$ & $\begin{array}{c}\text { Cumulative } \\
\text { percent }\end{array}$ \\
\hline \multirow{3}{*}{ gender } & male & 103 & 57.2 & 57.2 & 57.2 \\
\hline & female & 77 & 42.8 & 42.8 & 100.0 \\
\hline & sub Total & 180 & 100.0 & 100.0 & \\
\hline \multirow{5}{*}{ age } & 20 's & 70 & 38.9 & 38.9 & 40.6 \\
\hline & 30 's & 79 & 43.9 & 43.9 & 84.4 \\
\hline & 40 's & 25 & 13.9 & 13.9 & 98.3 \\
\hline & 50 's & 3 & 1.7 & 1.7 & 100.0 \\
\hline & sub Total & 180 & 100.0 & 100.0 & \\
\hline \multirow{5}{*}{ position } & employee & 101 & 56.1 & 56.1 & 59.4 \\
\hline & Assistant manager & 44 & 24.4 & 24.4 & 83.9 \\
\hline & manager & 24 & 13.3 & 13.3 & 97.2 \\
\hline & $\begin{array}{l}\text { More than department } \\
\text { manager }\end{array}$ & 5 & 2.8 & 2.8 & 100.0 \\
\hline & sub Total & 180 & 100.0 & 100.0 & \\
\hline \multirow{6}{*}{ career } & Less than 1year & 25 & 13.9 & 13.9 & 15.0 \\
\hline & $\begin{array}{c}\text { 1year or more } 2 \text { years or } \\
\text { less }\end{array}$ & 43 & 23.9 & 23.9 & 38.9 \\
\hline & $\begin{array}{c}3 \text { year or more } 6 \text { years or } \\
\text { less }\end{array}$ & 54 & 30.0 & 30.0 & 68.9 \\
\hline & $\begin{array}{c}\text { 6year or more } 9 \text { years or } \\
\text { less }\end{array}$ & 23 & 12.8 & 12.8 & 81.7 \\
\hline & More than 10years & 33 & 18.3 & 18.3 & 100.0 \\
\hline & sub Total & 180 & 100.0 & 100.0 & \\
\hline
\end{tabular}

\subsection{Exploratory Factor Analysis}

In this study, factor analysis was conducted to understand how sub-factors were classified for customer characteristics. Factor extraction method was performed by principal component analysis and Verimax rotation. As a result, it was excluded from some items that inhibit the validity of the 15 items, a total of 13 items were subjected to factor analysis (Melesse, 2019); (Mensah, 2019). KMO side was also shown to .880, the spherical test results of Bartlett also showed less than .000 significance factor analysis model was determined to be suitable. Cumulative dispersion appeared to be $71.568 \%$, it was determined that the descriptive power of the three factors configured is high. Factor load value is all appeared to be more than 0.4 , it was satisfied with the validity of the overall measurement tool. The analysis results are shown in [Table 3]. 
Table 3. Exploratory factor results

\begin{tabular}{|c|c|c|c|c|}
\hline \multirow{2}{*}{$\begin{array}{c}\text { variable } \\
\text { factor }\end{array}$} & \multicolumn{3}{|c|}{ factor } & \multirow{2}{*}{ commonality } \\
\hline & 1 & 2 & 3 & \\
\hline subordinate's friendship_3 & .864 & & & .812 \\
\hline subordinate's friendship_4 & .852 & & & .767 \\
\hline subordinate's friendship_5 & .825 & & & .731 \\
\hline subordinate's friendship_1 & .807 & & & .762 \\
\hline subordinate's friendship_2 & .800 & & & .735 \\
\hline co-worker's friendship_2 & & .829 & & .779 \\
\hline co-worker's friendship_1 & & .812 & & .716 \\
\hline co-worker's friendship_3 & & .791 & & .718 \\
\hline co-worker's friendship_5 & & .675 & & .574 \\
\hline supervisor's friendship_5 & & & .843 & .768 \\
\hline supervisor's friendship_4 & & & .835 & .742 \\
\hline supervisor's friendship_3 & & & .725 & .645 \\
\hline supervisor's friendship_1 & & & .715 & .555 \\
\hline Eigen-value & 3.719 & 2.841 & 2.744 & \\
\hline Common variance $(\%)$ & 28.610 & 21.850 & 21.107 & \\
\hline Cumulative variance $(\%)$ & 28.610 & 50.460 & 71.568 & \\
\hline
\end{tabular}

\subsection{Reliability Analysis}

Reliability analysis was conducted for the internal consistency of friendship with supervisor, friendship with co-worker, friendship with subordinates, job commitment, and customer orientation. The reliability is judged by calculating Cronbach's alpha. In general, if it is 0.7 or more, the reliability is judged to be good. The results of the results all appeared higher than 0.7 , the reliability of the main variables of the study was determined to be good. The analysis results are shown in [Table 4]

Table 4. Regression analysis results

\begin{tabular}{|c|c|c|c|}
\hline & variable & Cronbach's alpha & Number of items \\
\hline \multirow{3}{*}{$\begin{array}{l}\text { workplace } \\
\text { Friendship }\end{array}$} & subordinate's friendship & .918 & 5 \\
\hline & co-worker's friendship & .850 & 4 \\
\hline & supervisor's friendship & .838 & 4 \\
\hline \multicolumn{2}{|c|}{ job Commitment } & .779 & 2 \\
\hline \multicolumn{2}{|c|}{ customer Orientation } & .905 & 10 \\
\hline
\end{tabular}

\subsection{Correlation Analysis}

Pearson's correlation analysis was conducted to determine the correlation between the main variables of this study, friendship with the boss, friendship with the subordinates, job immersion, customer orientation. As a result, the friendship with the boss is a friendship with a colleague $(\mathrm{r}=.500, \mathrm{p}<.01)$, friendship with the subordinate $(\mathrm{r}=.400$, $\mathrm{p}<.01)$, job immersion $(\mathrm{r}=.443, \mathrm{p}<.01)$, customer orientation $(\mathrm{r}=.191, \mathrm{p}<.05)$ and both showed a significant fixed $(+)$ relationship, friendship with colleagues showed a significant relationship with the subordinate friendship $(\mathrm{r}=.499$, $\mathrm{p}<01)$, job immersion $(\mathrm{r}=.374, \mathrm{p}<.01)$, customer orientation $(\mathrm{r}=275, \mathrm{p} .01)$. Friendship with the subordinate showed a significant $(+)$ correlation with job immersion $(r=.348, \mathrm{p}<.01)$, customer orientation $(\mathrm{r}=.253, \mathrm{p}<.01)$ and all significant 
fixed(+), job immersion showed a significant correlation with customer orientation $(r=.341, \mathrm{p}<.01)$. Customer orientation showed a significant correlation between friendship with colleagues, friendship with subordinates, and job immersion. The analysis results are shown in [Table 5].

Table 5. Correlation analysis results

\begin{tabular}{cccccc}
\hline & $\begin{array}{c}\text { supervisor's } \\
\text { friendship }\end{array}$ & $\begin{array}{c}\text { co-worker's } \\
\text { friendship }\end{array}$ & $\begin{array}{c}\text { subordinate's } \\
\text { friendship }\end{array}$ & $\begin{array}{c}\text { job } \\
\text { Commitment }\end{array}$ & $\begin{array}{c}\text { customer } \\
\text { Orientation }\end{array}$ \\
\hline supervisor's friendship & 1 & & & \\
co-worker's friendship & $.500^{* *}$ & 1 & 1 & 1 & $.348^{* *}$ \\
subordinate's friendship & $.400^{* *}$ & $.499^{* *}$ & $.374^{* *}$ & $.253^{* *}$ & $.341^{* *}$ \\
job Commitment & $.443^{* *}$ & $.275^{* *}$ & & 1 \\
customer Orientation & $.191^{*}$ & & & \\
\hline
\end{tabular}

$* \mathrm{p}<.05, * * \mathrm{p}<.01, * * * \mathrm{p}<.001$

\subsection{Hypothesis Testing and Interpretation}

\subsubsection{Regression and Mediating Effect Analysis}

In order to verify the intermediary effect of job immersion in the relationship with the boss, friendliness with colleagues, and friendliness with subordinates to influence the customer orientation of the consultant, baron and Kenny proposed a hierarchy regression analysis was conducted. As a result, the regression model was shown statistically significant in step $1(\mathrm{~F}=18.919, \mathrm{p}<0.001)$, step $2(\mathrm{~F}=6.130, \mathrm{p}<0.001)$, step $3(\mathrm{~F}=7.690, \mathrm{p}<0.001)$ was all statistically significant, the descriptive force of the regression model is $23.1 \%$ in step 1 adjR2=.231\%), $7.9 \%$ in step 2 $\operatorname{adjR} 2=.079 \%), 13.0 \%$ in step 3 it appeared to be $\operatorname{adjR} 2=130 \%$. On the other hand, Durbin-Watson statistics were all evaluated as not a problem in the independent assumption of residuals showing a cool value in 2 , the distributed expansion index was also determined that there is no multi-fairness problem appears small to less than 10 . Based on the results of the regression analysis, the results of the indirect effect verification through bootstrap, the friendship with the boss, the friendship with the colleague, and the friendship with the subordinate all do not include 0 in the confidence interval. Job commitment has proven to be a mediator between the company's friends and the consultant's customer orientation. However, friendships with supervisors, colleagues with colleagues, and friends with subordinates do not have a direct impact on customer orientation, so there is no difference between friends, supervisors, colleagues, subsidiaries, and consultants. Job commitment was proven to play a full mediating role as an indirect effect. The analysis results are shown in [Table 6].

Table 6. Regression and mediating effect analysis

\begin{tabular}{|c|c|c|c|c|c|c|c|}
\hline $\begin{array}{c}\text { Dependent } \\
\text { variable }\end{array}$ & $\begin{array}{c}\text { Independent } \\
\text { variable }\end{array}$ & B & S.E. & $\boldsymbol{\beta}$ & $\mathbf{t}$ & $\mathbf{p}$ & VIF \\
\hline \multirow{4}{*}{ job Commitment } & (constant) & 0.805 & 0.326 & & $2.47 *$ & 0.014 & \\
\hline & $\begin{array}{l}\text { supervisor's } \\
\text { friendship }\end{array}$ & 0.324 & 0.081 & 0.310 & $4.013 * * *$ & 0.000 & 1.389 \\
\hline & $\begin{array}{l}\text { co-worker's } \\
\text { friendship }\end{array}$ & 0.180 & 0.103 & 0.143 & $1.749 *$ & 0.082 & 1.553 \\
\hline & $\begin{array}{l}\text { subordinate's } \\
\text { friendship }\end{array}$ & 0.156 & 0.079 & 0.153 & $1.980^{*}$ & 0.049 & 1.388 \\
\hline \multicolumn{8}{|c|}{$F=18.919(p<.001), R^{2}=.244,_{a d j} R 2=.231, D-W=1.718$} \\
\hline \multirow{3}{*}{$\begin{array}{c}\text { customer } \\
\text { Orientation }\end{array}$} & (constant) & 2.417 & 0.265 & & $9.111 * * *$ & 0.000 & \\
\hline & $\begin{array}{l}\text { supervisor's } \\
\text { friendship }\end{array}$ & 0.033 & 0.066 & 0.042 & 0.496 & 0.620 & 1.389 \\
\hline & co-worker's & 0.170 & 0.084 & 0.181 & $2.028 *$ & 0.044 & 1.553 \\
\hline
\end{tabular}




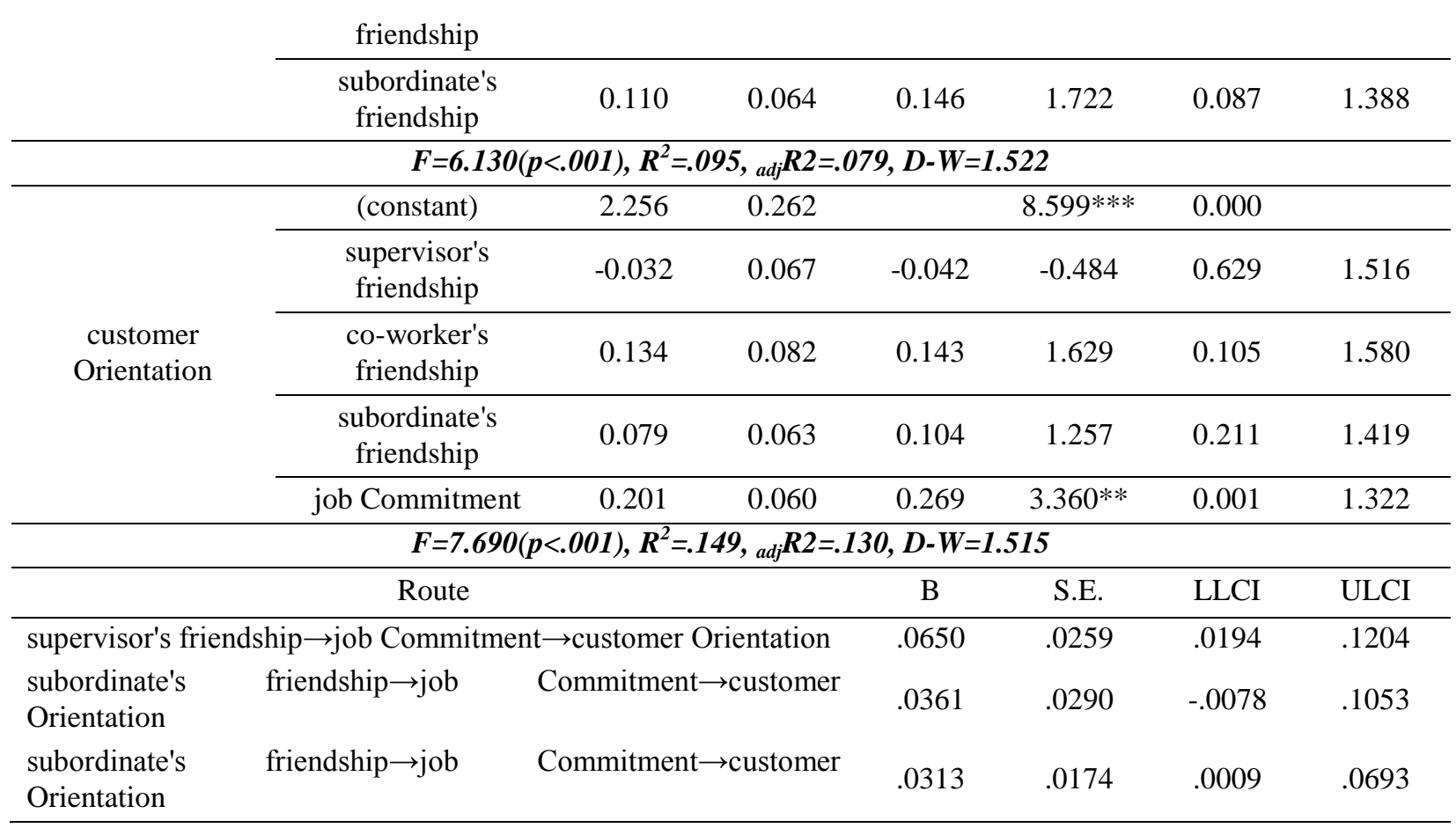

\subsubsection{Hypothesis Verification Summary}

In the significant verification results of the regression coefficient 1 step friendship $(\beta=.301, p<.001)$, friendship with colleagues $(\beta=.143, \mathrm{p}<.01)$, friendship with the subordinate $(\beta=.153, \mathrm{p}<.01)$ was shown significantly in the jung $(+)$. In other words, the higher the friendship with the boss, the friendship with the co-workers, and the higher the work immersion with the subordinate supat. In step 2 , it was found that the friendship $(\beta=.181, \mathrm{p}<.01)$ with a colleague is affected by a significant amount of the characteristics (+) customer orientation. In step 3, between friendship with the boss, friendship with a colleague, friendship with the subordinate and customer orientation $(\beta=.269, \mathrm{p}<.01)$ has been proven to play a complete intermediary role as an indirect effect (Mensah et al., 2019); (Monogbe Tunde et al., 2019); (Monogbe and Monogbe, 2019). The result of verifying the hypothesis is shown in [Figure 2].

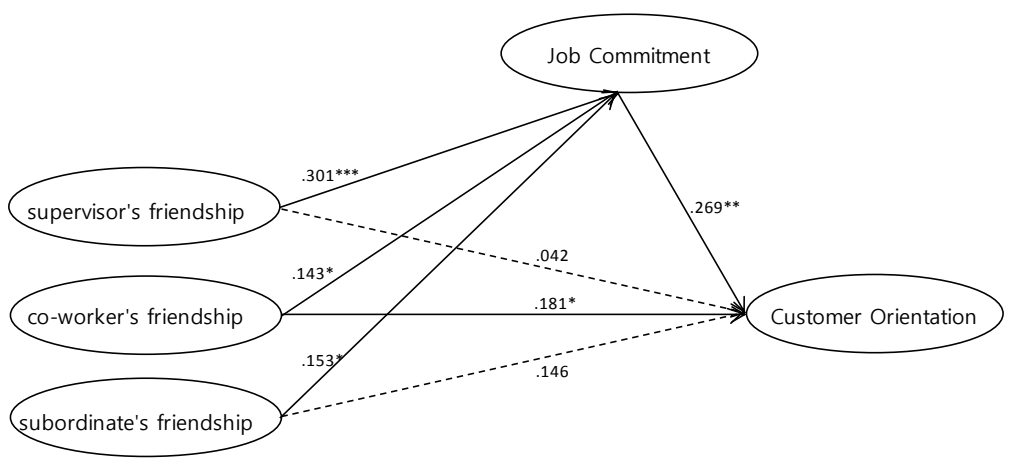

Figure 2. Hypothesis verification result

\section{Conclusion}

The purpose of this study is to focus on human services as a way of securing sustainable growth and competitive advantage of consulting firms. The purpose of this study is to empirically analyze the mediating effects of job commitment on influencing orientation. Friendships with supervisors, co-workers and subordinates in the workplace were found to have a positive effect on job commitment. Friendships with co-workers were found to have a positive 
effect on the consultant's influence on customer orientation. It was found that job commitment plays a role as a mediator between intimacy between supervisors, co-workers, subsidiaries, and customer orientation. This study tried to provide practical implications by analyzing the friendship among members of consulting firms whose role of human resources is very important in the organization. Therefore, as a way of securing sustainable competitiveness, the relationship between the level of workplace friendship and the consultant's customer orientation was confirmed. By multiplying the level of friendship with supervisors, co-workers, and subordinates, the group that has the most positive impact was identified to provide a practical contribution. Finally, if the limitations of this study are presented, it is necessary to consider the contract type of the members of the organization, the project status of each team, and the compensation system as control variables.

\section{Acknowledgment}

This research was financially supported by the Hansung University.

\section{References}

Chung, S. T. (2014). An empirical study on factors to purchase intention affected by clients under uncertainty of consulting services [Doctoral thesis]. [Seoul]: Graduate School of Knowledge Service \& Consulting, Hansung University.

Crosby, L. A., Evans, K. R., \& Cowles, D. (1990). Relationship qualityin services selling: An interpersonal influence perspectives. Journal of Marketing, 54(3), 68-81.

Deshpande, R., Farley, J. U., \& Webster, F. E. Jr.. (1993). Corporate culture, customer orientation, and innovativeness in Japanese firms: A Quadrad analysis. Journal of Marketing, 57, 23-27.

Hoffman, K. D., \& Ingram, T. N. (1991). Creatingcustomer-orientated employee: The case in home healthcare. Journal of Service Marketing, 11(2), 24-32.

Kang, J. K., \& Kim, H. K. (2008). Diagnosis of Korean Friendship. LG Business Insight, 2-21.

Kim, M. J. (2007). Comparison of job satisfaction, commitment to organization, nursing organization culture and intention of separation between national/public hospital nurses and private hospital nurses. Major in Nursing Administration Dept., of Medical Administration. [Seoul]: Graduate School of Public Administration Kyung Hee University Directed by Prof..

Lee, J. H. (2000). Human resource management. Seoul: Kyungmoon.

Levitt, T. (1980). Marketing success through differentiation of anything. Harvard Business Review, 58, 82-91.

Melesse, W. (2019). Business cycles and financial frictions under money growth rule. Asian Journal of Economics and Empirical Research, 6(1), 16-26. https://doi.org/10.20448/journal.501.2019.61.16.26

Mensah, D. K. (2019). Teachers' perspective on implementation of the double track senior high school system in Ghana. International Journal of Emerging Trends in Social Sciences, 5(2), 47-56. https://doi.org/10.20448/2001.52.47.56

Mensah, O. S., Jianlin, C., \& Jun, J. Y. (2019). A quantile regression analysis of contributing factors influencing agribusiness growth and entrepreneurship development: Evidence from rural China. Asian Business Research Journal, 4, 10-16.

Monogbe Tunde, G., Austin, A., Uzowuru Lawrence, N., \& Edori, D. (2019). Sectoral credit allocation of deposit money banks and poverty reduction in Nigeria. International Journal of Business, Economics and Management, $6(1), 49-60$.

Monogbe, B. O., \& Monogbe, T. G. (2019). ASUU strike and Nigerian educational system: An empirical investigation of the Nigerian tertiary institution. American Journal of Social Sciences and Humanities, 4(1), 56-67.

Mowday, R. T., Steers, R. M., \& Poter, L. W. (1979). The measure of organizational commitmet. Journal of Vovational Behavior, 14, 142-147, 224-247.

Riordan, C. M., \& Griffeth, R. W. (1995). The opportunity for friendship in the workplace: An underexplored construct. Journal of Business and Psychology, 10(2), 141-154.

Saxe, R., \& Weitz, B. A. (1982). The SOCOS cale: A measure of the customer orientation of salespeople. Journal of Marketing Research, 22, 243-251. 